\title{
BIOGEOGRAPHICAL DIVERSITY OF NORTH MESOREGION OF THE MARANHÃO STATE
}

\author{
(BRAZIL)
}

\author{
Lianne Pollianne Fernandes Araújo Chaves ${ }^{1, *}$; Raimunda Alves Silva² Yuri Teixeira Amaral ${ }^{3, a}$; \\ Mayanna Karlla Lima Costa ${ }^{4}$ and Glécio Machado Siqueira ${ }^{5}$
}

\begin{abstract}
${ }^{1}$ Doutoranda no Programa de Pós-Graduação BIONORTE, Universidade Federal do Maranhão, São Luís, Brazil. ${ }^{2}$ Mestranda no Programa de Pós-Graduação em Ciência Animal, Universidade Federal do Maranhão, São Luís, Brazil. ${ }^{3}$ Mestrando no Programa de Pós-Graduação em Biodiversidade e Conservação, Universidade Federal do Maranhão, São Luís, Brazil. 4Doutoranda no Programa de Pós-Graduação BIONORTE, Universidade Federal do Maranhão, São Luís, Brazil. ${ }^{5}$ Professor, Departamento de Geociências, Universidade Federal do Maranhão, São Luís, Brazil. a)|nstituto Chico Mendes de Conservação da Biodiversidade.

* Corresponding author: liannepolliannekl@yahoo.com.br
\end{abstract}

ABSTRACT: Maranhão North Mesoregion has the highest demographic density of the state because where is located the capital, São Luís. The climate is humid or sub-humid tropical with rainfall rates around 1,000 mm / year, and suffering, this way, the mass influence of air. The coastal plain of Maranhão is subdivided into four geomorphological sectors: to the west-northwest coast, which is marked by State recesses, specifically maranhense Golfão; the east coast where dominate the fields of movable or fixed dunes; and the deltaic plain of the Parnaíba River. This study aimed to present a panorama of the North region of Maranhão State demographic density focus, economic sectors, and biological diversity. With regard to the economic sector, the northern region, one of the highlights are the Lençóis maranhenses, the main geo-touristic attractive in relation to its natural beauty and to its mysteries, rivers, mangroves, moving dunes and interdune lagoons, constituting areas of magnificent landscapes, with favorable conditions for recreational tourism. In the extreme north of the state, is found the baixada maranhense that is considered one of the most beautiful state tourist centers, characterized by extensive plains, rivers, estuaries, mangroves and flooded fields, having as highlight, the floating islands of Formoso, Lontra, Cajari and Capivari lakes, in the city of Penalva. In terms of biological diversity, the North Region is dominated by the Amazon forest, which has specific characteristics of the tropical forest. The fauna of the region is typical, with the presence of large and medium-sized animals and many arthropods already reported to the state. The vegetation comprises trees of the Amazon domain, however, is easily found plants of the cerrado biome and babassu palms. In general, the region stands out for its natural beauty and constitute an important economic center.

Key words: São Luís Island, Maranhense Amazon, Maranhão State.

\section{DIVERSIDADE BIOGEOGRÁFICA DA MESORREGIÃO NORTE DO ESTADO DO MARANHÃO (BRASIL)}

RESUMO: A Mesorregião do Norte Maranhense possui a maior densidade demográfica do Estado, pois é onde está localizado a capital, São Luís. O clima da região é tropical úmido ou subúmido com índices de precipitação entorno de 1.000 mm/ano, sofrendo assim influência de massas de ar. A Planície Costeira do Maranhão é subdividida em quatro setores geomorfológicos: a costa oeste-noroeste que é marcada por reentrâncias do Estado, especificamente o Golfão maranhense; a costa leste onde predomina os campos de dunas móveis ou fixas; e a planície deltaica do rio Parnaíba. Neste trabalho objetivou apresentar um panorama da região norte do Estado do Maranhão com enfoque densidade demográfica, setores econômicos e diversidade biológica. No que tange ao setor econômico a região norte, um dos destaques é os Lençóis maranhense, principal atrativo geoturístico no que se refere às suas belezas naturais e aos seus mistérios, rios, mangues, dunas móveis e lagoas interdunas, constituindo áreas de paisagens magníficas, com condições favoráveis para turismo de lazer. No extremo norte do Estado, encontra-se a baixada maranhense é considerado um dos mais belos polos turísticos do Estado, caracterizada por extensa planície, rios, estuários, mangues e campos alagados, tendo como destaque as ilhas flutuantes dos lagos Formoso, Lontra, Cajari e Capivari, no município de Penalva. Em termos de diversidade biológica, a região norte é dominada pela floresta amazônica, que possui características especifica de floresta tropical. A fauna da região é típica, com presença de animais de grande e médio porte e muitos artrópodes já relatados para o Estado. A vegetação compreende árvores do domínio amazônico, porém é facilmente encontrado plantas do bioma cerrado, e palmeiras de babaçu. Em geral, a região destaca-se pelas belezas naturais e por constituir um importante centro econômico.

Palavras-chave: Ilha de São Luís, Amazônia maranhense, Estado do Maranhão.

Received: Aug. 10, 2016 - Accepted: Nov. 23, 2016 


\section{INTRODUCTION}

The State of Maranhão, according to the Brazilian Institute of Geography and Statistics (IBGE, 2002) comprises a surface area of $331,983.29 \mathrm{~km}^{2}$, being the second largest state in the Northeast and the eighth in the Brazilian federation. The boundaries, to the north, is the Atlantic Ocean, to the south the State of Tocantins, to the eastern the State of
Piaui and to the west the state of Pará. The whole state is composed of 217 cities and is geographically divided into 21 microregions with features in common. In terms of population density, the state is divided into two large metropolitan regions, the great São Luís and the southwest region of Maranhão (Figure 1).
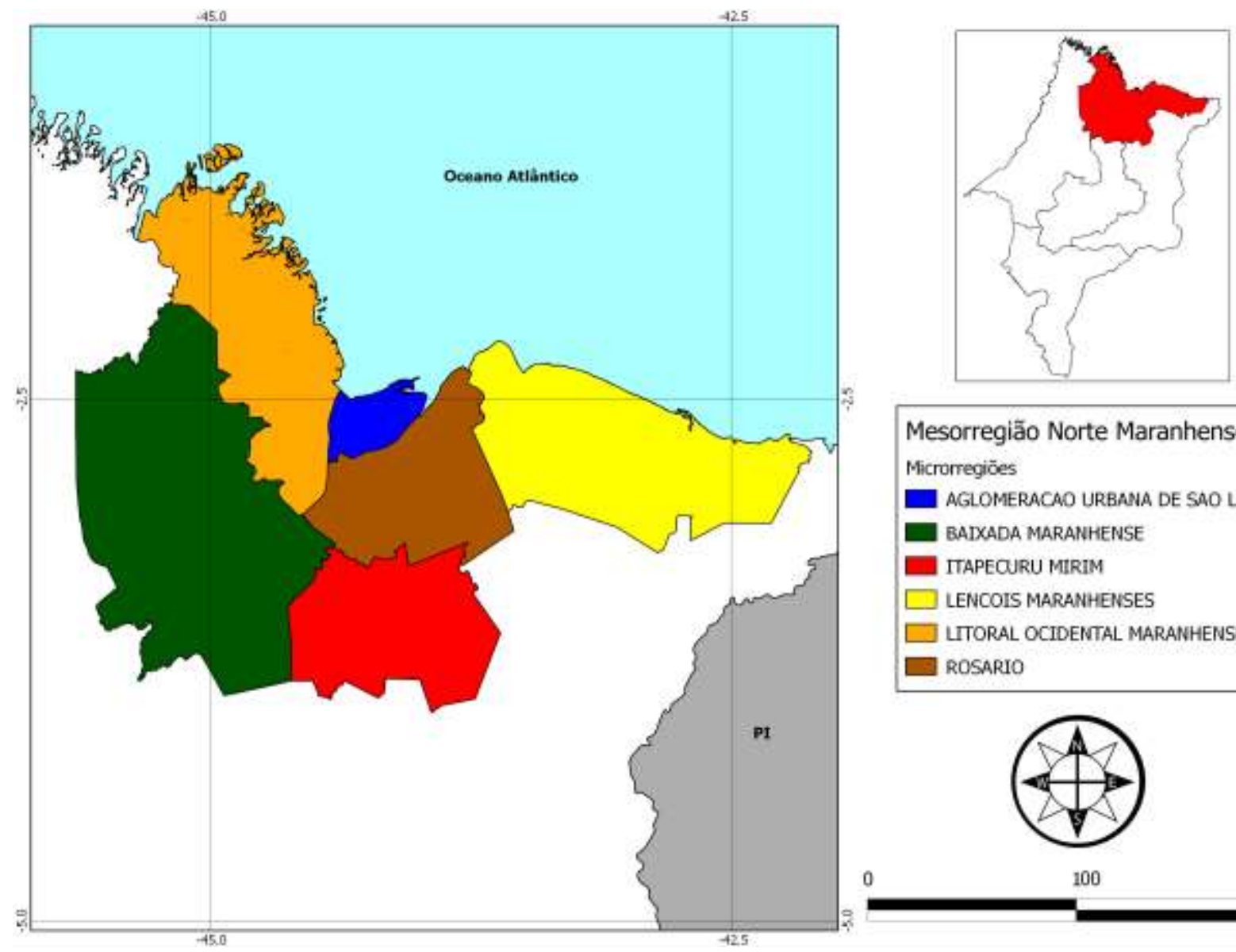

Mesorregiăo Norte Maranhense Micromegiöes

- aGLOMERACAO URBANA DE SAO LUIS BAIXADA MARANHENSE TTAPEQURU MIRIM LENCOIS MARANHENSES UTORAL OCIDENTAL MARANHENSE ROSARIO

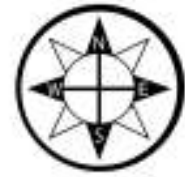

100 $200 \mathrm{~km}$

Figure 1. Location of the northern region of the State of Maranhão).

\subsection{Maranhense Northern Region}

The Maranhense Northern Region is the region that presents the largest absolute population with 2,410,524 inhabitants, corresponding to $42.65 \%$ of the state and, equally with the highest population density
(45.81 habs $/ \mathrm{km}^{2}$ ) (IBGE, 2010). Corresponds to the Coastal Region of Maranhão, with an approximate length of $640 \mathrm{~km}$, extending from west- east direction of the Gurupi Estuary (PA/MA) until the Americas' Delta (MA/PI), (Costa et al., 1991). The climate is moist or sub most tropical type, with annual temperatures higher than $18{ }^{\circ} \mathrm{C}$ and rainfall 
higher than 1,000 mm/year with the influence of the convergence of the Equatorial Atlantic and Continental air masses (Sousa, 2007).

The Coastal plateau of Maranhão spreads by a wide coastal fringe and represents a geomorphological domain that can be subdivided into four markedly differentiated sectors, according to Feitosa (2006): the moist west-northwest coast of Maranhenses Recesses, dominated by vast tidal plateaus (mangroves); its most pronounced recess, constituted by the Golfão Maranhense; the east coast, of semi-moist climate, dominated by extensive fields of moving or fixed dunes; generating, in its retro area, wide fluvialmarine plateau of extremely flat topography and practically adjusted to the level of general base, called Baixada Maranhense; and the deltaic plateau of the Parnaíba River (, Teixeira and Souza Filho, 2009; Bandeira 2013).

\subsection{Golfão Maranhense}

It is the largest recess of the state's coast and is located between the West and East coast of Maranhão. Covers the enclosed recess, to the west, by the edge of Guajuru, in the city of Cedral, and to the east, by Santaninha Island, in the city of Humberto de Campos, having, at the center, Upaon-Açu island, better known as Maranhão island or São Luís island, besides the islands of Medo, Pequena, Livramento, Caranguejos, Duas irmãs, Tauá-Redonda, Tauá-Mirim and Ponta Grossa and comprising the Bays of Cumã, São Marcos, São José and Tubarão (Bandeira, 2013) (Figure 2).

With a surface of about $905 \mathrm{~km}^{2}$, the Upaon-Açu Island is composed of three cities São Luis, São José de Ribamar and Raposa, locating in the geographical center and serving as a natural physical divider between São Marcos Bay and São José de Ribamar Bay. In 2010, a total of 1,309,330 inhabitants, $77.50 \%$ used to live in São Luís, $12.45 \%$ in São José de Ribamar, $8.03 \%$ in Paço do Lumiar $2.01 \%$ in Raposa, which confirms an even greater population concentration in São Luís city. The bays of São Marcos and São José are considered the most important of the coastal zone of Maranhão by both the physiographic aspects, being water outlets of the largest rivers of the State and present intense dynamics of the landscape, as by the density of human activities and the circulation of wealth (Silva, 2012).

The climate of Maranhão Island is characterized as rainy tropical, with dry periods in the winter; and hot with summer rains, by obeying the Köppen classification (Köppen, 1918; Smith, 2012); and hot and moist, with equatorial features.

The basins of Bacanga, Tibiri and Paciência are the three main of Maranhão Island, beyond that, have smaller basins that are from the Mosquitos, Jaguarema, Arapapá, Tijupá, Anil, Jeniparana, Cachorros and Santo Antônio rivers. The Bacanga and Anil rivers shed their waters in São Marcos bay and in Paciência, Santo Antônio, Jeniparana, and Tibiri Rivers, in São José bay, have still the Cachorros stream that flows into the west, in the narrow of Coqueiros, in São Marcos bay (Silva, 2012).

The landscape dynamics in the Golfão Maranhense area is facilitated by the fragility of the geological structures, by their exposure to modeling agents of relief as the climatic origin, hydrological and oceanographic, and by the intense wind, marine and fluviomarine, generating waves and currents that model the 
larger set of cliffs of the coast of Maranhão, and the continental sediment supply carried by the rivers.

The coast of Golfão is classified as a wind constructional coast, corresponding to the stretch: dune fields and salt Marsh constitute São José Bay - in the north coast in São Luís
Island. The beaches are dynamic and fragile environments; besides presenting the coastal protection function for the surrounding ecosystems, is the habitat for many plants and animals species and space for urban and rural activities, recreation and tourism.
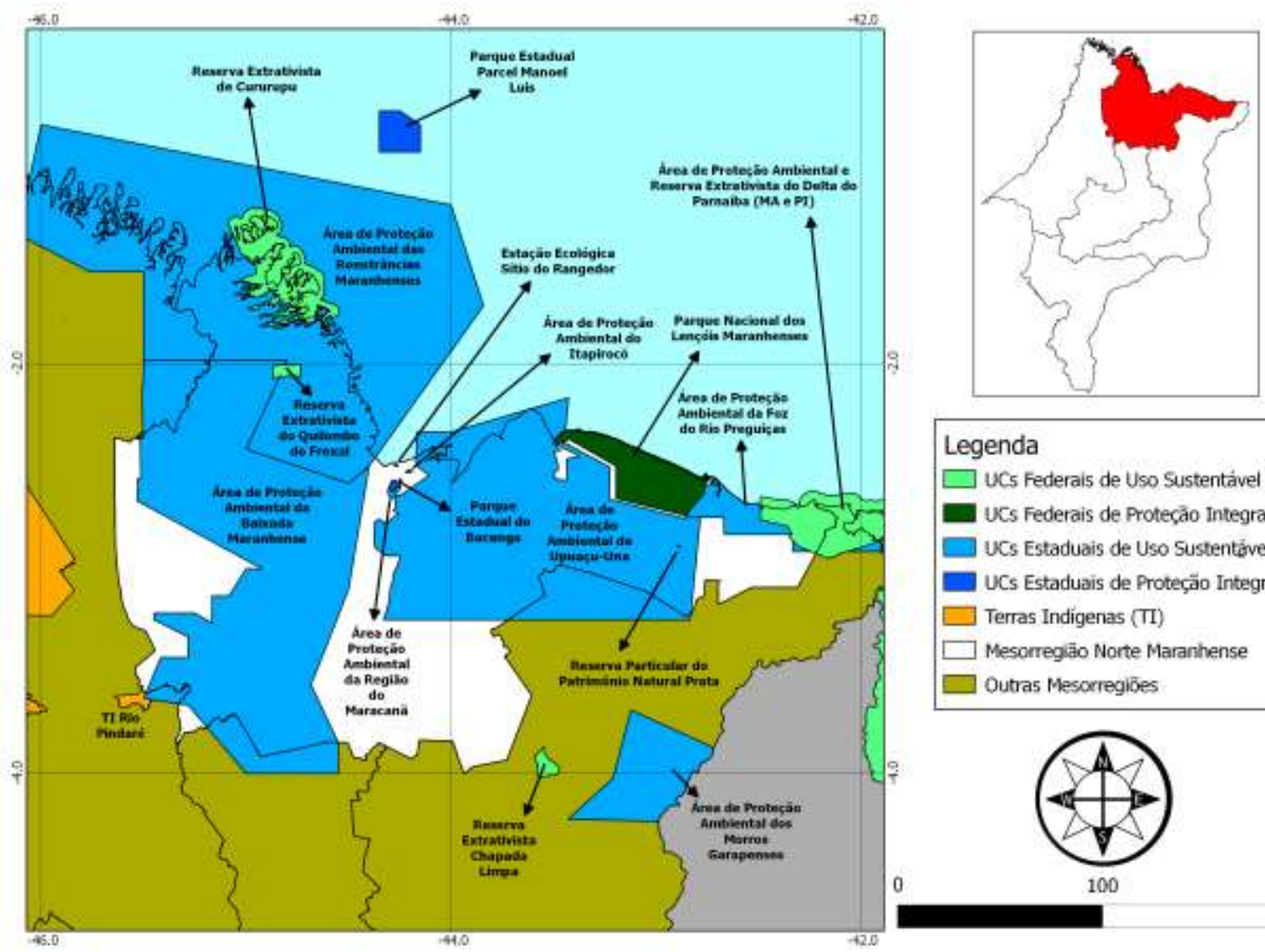

\section{Legenda}

$\square$ UCS Federais de Uso Sustentävel

ucs Federais de Proteça Integral

UCs Estaduais de Uso Sustentävel

UCS Estaduais de Proteçäo Integral

Terras Indigenas (TI)

Mesorreglio Norte Maranhense

Outras Mesocregib̄es

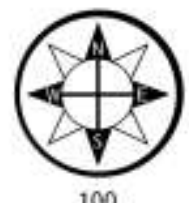

100

$200 \mathrm{~km}$

Figure 2. Map of the Coastal Zone of Maranhão State (Brazil).

To the west of São José Bay and along of the Cumã Bay, the Golfão Maranhense is sharply bounded by cliffs and tabular hills of the Coastal boards from Alcantara-Guimarães (Bandeira, 2013).

The boards of São Luís and AlcântaraGuimarães, called Coastal boards Maranhenses by IBGE (2011c), are supported by sediments of the Barrier Group or, subordinately, by thick very weathered sandstones regolith of Cretaceous age, of Itapecuru Formation. To the north, the boards end up, sometimes, abruptly, through cliffs and paleo-cliffs with extensive fluviomarine plains and mangroves of the northwest coast of Maranhão. On these grounds, used, largely, for agricultural activities, it does develop in the very deep soil, well drained, very friable and of low natural fertility, thick and leached, predominantly Latosols Yellow and dystrophic 
Red-Yellow. Subordinately, soils are registered with textural gradient, deep, more susceptible to erosion than the Latosols, which correspond to dystrophic Red-Yellow Argisols, and soils with current drainage problems, as Haplic Plinthosols. (IBGE, 2011a).

On São Luís Island, The Jansen Lagoon occupies an area of 130-150 ha. (IBAMA/SEMATUR, 1991). It is constituted by a body of water and has its anthropic origin with a little communication with the sea when of the spring tides. Mangroves occupy the shores.

Registers, in the Golfão Maranhense region, more precisely on the São Luís island, the implementation of Itaqui Port, IndustrialPort complex (Itaqui and the terminals of Ponta da Madeira) headed for minerals export (particularly, iron ore and bauxite) from the Mineral Province of Carajás by Companhia Vale do Rio Doce, also stands out the mercantile activity is the service sector employing large contingent of workforce of the State. The towns of Alcantara and São Luís has great potential for historical tourism and geo-tourism. (Novaes et al., 2007; Souza and Feitosa, 2009).

\subsection{East coast}

It found between the Golfão Maranhense and the mouth of the Parnaíba River, with a population of 155,215 inhabitants (13.12 inhabitants $/ \mathrm{km}^{2}$ ) (IBGE, 2010), is marked by a coastal sub-rectilinear, with dune formations, sandy beaches, and bays. The Lençóis Maranhenses cover the central-eastern portion of Maranhão coastal plain positioned between the bays of São Luís and Tubarão, to the west; and the Parnaiba Delta, to the east (Bandeira, 2013).
The climate is the sub-moist tropical type, with annual temperatures above $18{ }^{\circ} \mathrm{C}$ and rainfall exceeding $1,000 \mathrm{~mm} / \mathrm{a}$. The rainfall regime defines two seasons: the rainy season, which corresponds to the months of summer and fall, with higher rates in March and May, and the other, is dry with a total monthly rainfall lower than $60 \mathrm{~mm}$ in the driest months, which corresponds to winter and spring (Maranhão, 2002). The vegetation cover consists of small residual patches of the vegetation of shrubby standard, classified as pioneer Formation, which is composed of vegetation with marine influence, dunes vegetation and Restingas (Ferri, 1980) and small patches of mangroves and Cerrado.

The hydrographic system of the village area is constituted by the contiguous ocean area and a set of lagoons, many of them permanent, which totally depend on rainfall. The drainage of the area gets at left bank tributaries receives the influence of the Preguiças river basin that has an extension of $3,950 \mathrm{~km}^{2}$ representing the large local expression, but not performing an important role in the regional economy (Rabelo, 1992). Another feature of the hydrographic area is the presence of lagoons that are fed only by rainwater, directly and indirectly way, through the groundwater, developing flora and fauna from the water accumulation. These lagoons, in its majority, dry up during the dry season, a consequence of the evapotranspiration and percolation.

The geology of the village consists of unconsolidated sedimentary formations of Quaternary age, floodgate almost exclusively by quartz sands of fine to very fine granulometry, from the adjacent oceanic area, that covers part of the top of the sedimentary basin of Barreirinhas being, 
subsequently, carried to the beach by climatic and oceanographic agents (Smith, 2005). In this area was recognized the presence of sandy-quartzitic soils and Halomorphic soils. (Barbosa e Pinto, 1973).

The Lençóis Maranhenses are located between the coastline and the fluvial plain of the Munim River and the Coastal boards of Chapadinha region, being these, in large part, sustained by little lithified sedimentary rocks of the Barrier Group. They can be subdivided in two ways. First, highlights the contrast between moving and fixed dunes. The moving dunes, predominantly of barchans type (Gaston and Maia, 2010), of great scenic beauty and with accumulations that reach 30 to $40 \mathrm{~m}$ high, they occupy more limited area along to coastline, close to the localities of Santo Amaro do Maranhão, Barreirinhas, Paulino Neves and Tutoia. In its rear, vast fields of fixed dunes over quaternary plains or climbing the coastal plains are developed, coated with pioneer or field-cerrado vegetation. These dune fields, which spread among the boards of the Barrier Group, extend from 50 to $120 \mathrm{~km}$ into the interior, reaching the localities of Urbano Santos and Santana do Maranhão (Bandeira, 2013).

Lençóis Island is one of the main geotouristic attractions in relation to its natural beauty and its mysteries, rivers, mangroves, moving dunes and interdune lagoons, constituting magnificent landscapes areas, with favorable conditions for recreational tourism.

On the eastern edge of the Coastal Plain of Maranhão, develops the Parnaiba Delta, the most well delineated deltaic feature in a fluvial fan of the Brazilian coast (Ab'Sáber, 1960), located between the states of Piauí and Maranhão. The western portion of the
Parnaiba Delta is located in the State of Maranhão and is bounded, to the south and west, by the Lençóis Maranhenses.

This unit, characterized by an interface deltaic environment between the fluvial and marine sedimentary systems, presents a diversified set of depositional features of fluvial origin, fluviomarine, wind and marine, with marked domain fluviomarine plain and mangroves. Stands out, however, the occurrence of distributary channel parallel to the coastline, blocked by sand strings, sometimes reworked in dune fields generated along the coast. In this low energy environment in the inside, the deltaic plain is developed extensive areas of mangroves. The mangrove vegetation has great importance for the bio-stabilization of fluviomarine plain and in the deposition of fluvial sediments on its shores. In the deltaic plain of the Parnaíba River, the mangroves work as a damping area of the impacts provoked by river flooding and advances of the sea (Ferreira and Dantas, 2010). Added to its ecological importance, because it is a nursery for breeding of several species of crustaceans and fishes. Only the amount of Araioses locality is observed a typical alluvial sedimentation, generating the broad low course floodplains of the Parnaíba River.

The Parnaiba Delta also has deltaic environment presents different features with high geo-touristic potential, such as: beaches, lagoons, mangroves, rivers, fixed dunes associated with sandbanks vegetation and coastal Caatinga and moving dunes, being the only deltaic feature of the Americas located in open sea and the third largest ocean delta in the world (Maranhão, 2011). 


\subsection{West Coast}

It corresponds to the coastal segment of Maranhão recesses, which comprises São José Bay stretch and mouth of the Gurupi River, having as bound the tip of Chrysobalanus icaco in the city of Cedral, consists of the most extensive plain of continuous tide in the world, reaching $650 \mathrm{~km}$ of extension and $7,500 \mathrm{~km}^{2}$, which corresponds to more than half of the entire length of mangroves in Brazil (Bandeira, 2013).

This region corresponds the Maranhense Amazon pole, covering the cities of Turiaçu, Cândido Mendes, Luís Domingues, Godofredo Viana and Carutapera, dominated by the equatorial climate with average rainfall between 1,800 and 2,500 $\mathrm{mm}$ per year. Is notable by its extremely indented boundary in rias and estuaries (Barbosa and Novaes Pinto, 1973), alternating prolonged spigots of mangroves and salt plains, often anchored by sand ridges. Among these estuarine areas with paleocliffs modeled by the Trespass Flandrian of Holocene age, stand out the "bays" of Gurupi, Turiaçu and Cumã, corresponding, also to the mouth in the shape of the estuary ria of the rivers homonyms.

The unit, generated in depositional environment of macro tides, presents a set of depositional features of fluvial and marine origins. This domain covers extensive fluviomarine plains, highlighting the occurrence of exiguous and coastal floodplains. It stands out, in this context, vast domain of low and floodable land. With sprawling covering interface of pioneer formations between continental and marine environments, occupied by vast mangrove. The plains fluviomarine intertidal, consisting of unconsolidated sediments of Holocene age, consist of clay or clay-sandy land, rich in organic matter, characterized as mangrove Soil, Salics Gleysols and Tiomorphics Gleysols (IBGE, 2011a).

Mangroves are often provided on the shores of estuarine waters. With extensive emersed muddy plains during low tides. Hypersaline everglades, apicuns, freshwater swamps and lowland forests usually occur behind the strip of mangroves, toward the mainland. (Senna and Sarmento, 1996; Prost et al., 1997). Mangroves are under pressure from erosion and deposition that can act as tensors affecting the root system by avoiding the fixation and the breathing trees.

Despite the great environmental fragility of these lands, dominated by extensive mangroves, the process of human occupation undertaken by traditional communities with a dwindling population, based on traditional fishing and extraction, has not promoted significant environmental impacts in the region (Souza and Feitosa, 2009).

Currently in the mangroves a superexploitation of resources, where the man withdraws oysters, crustacean (sururu, represented by two species: Mytella falcata and $M$. guyanensis), fish and wood in high quantities. The mangrove crab (Ucides cordatus L.) constitutes as one of the main estuarine fisheries resources, because of its high abundance and facility in its capturing, which does not require methods and sophisticated techniques, thereby preventing the effective control of its total production (Castro, 1986).

The main attractions of the West Coast are based on the biodiversity of the Amazon forest, mangrove forests and mangroves geodiversity, rivers, wild beaches and rapids, 
as well as the culture of quilombo communities.

\subsection{Marine State Park Manoel Luis Parcel}

The not inhabited region sets the largest coral bank in South America, is a Brazilian conservation unit of full protection, constituting the most important matrix of marine species, with small outcrops of seaweed during low tide (MMA, 1996), that occurs at 49 miles from the coast and is linked to the city of Cururupu.

\subsection{Baixada Maranhense}

Baixada Maranhense is located at the northern end of the state of Maranhão, covers 21 cities, has 1,775,035.6 hectares of extension, and has a population of 190,493 inhabitants. (22:42 inhabitants / $\mathrm{km}^{2}$ ) (IBGE 2010). Ecosystems located in the transition zone between the Amazon and Cerrado biomes, with influence of coastal and marine environments, highlighting wetlands that provide habitat for several aquatic species, including birds, in abundance, as well as plant species that are important to the economy of the local population.

Represented by an extensive inland plain is constituted by a seasonally flooded surface of freshwater marshes (or hydrophilic fields floodplain), intermittent lakes, halophiles fields floodplain, salt marshes (or apicuns), mangroves, muddy tidal flats (or crowns mud) and estuarine channel (Teixeira and Souza Filho, 2009), where converge the main rivers genuinely Maranhense: Itapecuru, Munim, Mearim, Grajaú and Pindaré; Typical plains river, characterized by low slope in the middle and lower stretches. It is a "Pantanal Maranhense".

Composed by three geo-facies corresponds to flooded areas and /or subject to flooding in altimetric elevations ranging from 20 to $55 \mathrm{~m}$, constituted by Holocene fluvial-marine deposits where the Gleysols and Alluvial Soils dominate, covered by vegetation of Alluvial Pioneer formations. This area is used by the fishing activity and the search of shellfish. Near the coast occur the fluviomarine plain with Indiscriminate Mangrove soils and interfluvial plans, the dominant soils are Plinthosols and the vegetation cover is secondary to the vegetation of the forest plus Alluvial Pioneer formations and agriculture with buffalo's creation predominantly. The regional climate is moist with annual rainfall ranging from 1700 to $1900 \mathrm{~mm}$. In this unit, dominate the unstable environments with very high vulnerability. In fluvial-lake plains of Baixada Maranhense highlights: Anajatuba, Cajapió, Viana, Cajari, Arari and Vitória do Mearim (Bandeira 2013).

The fields of this region known as Baixada Maranhense are characterized by a graminoid-herbaceous physiognomy in moist and flooded areas and on the periphery of the watercourses and marshes, with a predominance of Gramineae. In certain places, it presents shrubby, receiving the denomination of "tezos". Periodic flooding of those rivers listed above is the main former element of these fields (IBGE, 1962). The babassu or coconut groves are a type of characteristic ecosystem of the area, houses either forest patches of pre-Amazonian land.

The Baixada Maranhense is considered one of the most beautiful touristic centers of the state, characterized by extensive fluviallagoon plains, rivers, estuaries, mangroves 
and flooded fields, having as highlight the floating islands of the lakes Formoso, Lontra, Cajari, and Capivari, in the city of Penalva. It enhances the natural phenomenon of pororoca in the city of Arari, located in the lower course of Mearim River, whose waters, episodically, are barred by the force of the ocean waters, which due to the large spring tide amplitudes, advance over the estuarine bay zone of São Marcos, in Golfão Maranhense, and invade the mouth of the Mearim River. Currently, there is great interest in this phenomenon by extreme sports enthusiasts, especially for surfing practicing, which sets as peculiar attractive geo-touristic in this poor region of Baixada Maranhense (Bandeira, 2013).

The extractive activity of babassu, although economically it is not a profitable activity, presents with high social importance because it is constituted as an alternative income for the low-income population throughout the state, as this crop is grown throughout the predominance area existing secondary vegetation and livestock development activities with rustic species such as buffalo cattle in other areas, including subjected to flooding.

\section{BIODIVERSITY}

Overall, the northern region is the Amazon biome domain, being this the most extensive, housing the largest rainforest in the world. In the state of Maranhão, the Amazon forest is the concept of Legal Amazon created by the government in the 1950s so that the tax benefits could reach the north of the country and thus to promote the development. The territory area of the Legal Amazon is
$5,217,423 \mathrm{~km}^{2}$, corresponding to about $61 \%$ of the national territory. The northwest and west of the state, representing about 35\% of the territory, with $81208,40 \mathrm{~km}^{2}$ with 62 cities (IBGE, 2002).

\subsection{Vegetation}

The vegetation of Maranhão Amazon is composed of dense Atlantic Rainforest $\left(21,655 \mathrm{~km}^{2}\right)$, Open Atlantic Rainforest $(2,089$ $\left.\mathrm{km}^{2}\right)$, Semidecidual Seasonal Forest $(3,698$ $\left.\mathrm{km}^{2}\right)$, deciduous seasonal forest $\left(133 \mathrm{~km}^{2}\right)$, Ecotone $\left(236 \mathrm{~km}^{2}\right)$ (IBGE, 2002).

The flora of the northern of Maranhão is extremely rich and diverse, however, when taking into account the floristic and phytosociological inventories, and realizes that there is little information about the total species. The flora reflects the climate and soil conditions of the transition environments. Muniz (2011) claims that in structural terms the vegetation is quite similar to the Amazon rainforest, with dominant species and botanical families, little abundance, indicative of high diversity. The same author also pointed out that the main families are Leguminosae, Sapotaceae, Moraceae, Burseraceae, Sapindaceae, Euphorbiaceae, Apocynaceae, Annonaceae, Lecythidaceae, Rubiaceae, Lauraceae, Bignoniaceae, Meliaceae and Rutaceae.

Regarding the ethnobotanical knowledge, Rego and Oliveira (2011) conducted an inventory in three phases of studies in the cities that compose the Legal Amazon, and identified 33 families, 80 genera and 80 species highlighting the Gramineae, Fabaceae, Annonaceae, Apocynaceae families in the first stage, where was visited 20 cities. In the Amazon Baixada were evidenced 35 families, 
67 genera, and 67 species, being the most represented families Leguminosae, Labiatae, Graminae, Rutaceae, and Moraceae.

\subsubsection{Sandbank}

The sandbank vegetation in Maranhão state comprises about $650 \mathrm{~km}$ from the coast (El-Robrini et al., 2006). It is composed of herbaceous species, can be found until arboreal individuals. Sierra et al. (2016) in the floristic survey in São José de Ribamar identified 116 species, distributed among 100 genus and 52 families. The most represented families were Fabaceae (18 species); Cyperaceae (9); Rubiaceae (8); Myrtaceae (5); Poaceae (4), Asteraceae (4); Malvaceae (4); Combretaceae (3) and Eriocaulaceae (3). The authors report that of the 116 species, 19 new records for the state, where these species of Maranhão sandbank form a group with the Pará State species, which leads to the conclusion that possibly, were colonized by the same population.

\subsubsection{Mangrove}

The vegetation of this ecosystem is composed of herbaceous species, tolerant to salinity, such as Batis maritima, Blutaparon portulacoides and Sesuvium portulacastrum. In Maranhão, the tree species are divided into Red Mangrove - Rhizophora mangle, Rhizophora racemosa and Rhizophora harrisonii; the Siriba, Avicennia germinans and Avicennia schaueriana; and the tinteira, Laguncularia racemosa, button mangrove Conocarpus erectus and fern-the-swamp, Acrostichum aureum.

\subsection{Fauna}

In Maranhão, some studies have characterized some specific groups, such as bees, dipteran, mammals and fish fauna.

Bees are the most inventoried in North of Maranhão, according to Rabelo et al. (2011) in this group has been sampled 44 species of Apidae distributed in four genera, Euglossa (25 species), Eufriesea (11), Eulaema (5) and Exaerete (3), being that the greatest diversity is recorded to the north of Maranhão (45 species) and São Luis Island (22 species). Silva and Rabelo. (1999) emphasize that the greatest richness of bee fauna is found in the western part, where there are moister vegetation formations with typical Amazonian species, as the state extends to the east, where the vegetation is more open, the composition of Apidae is modified. The bees have an important role in nature and are responsible for a fundamental process for the plant, as the pollination.

Still concerning the fauna of Hymenoptera, Matos et al. (2016) on sampling in the city of North Miranda, identified eight families and 17 species. In Sphecidae family the genus Isodontia was sampled 250 individuals that were not identified to species level, being distributed in Isodontia sp 1 (145 individuals), Isodontia sp 2 (80), Isodontia sp (13), Isodontia sp (11) and Isodontia sp (1), which may possibly constitute new species or first records for the State. Oliveira et al. (2016) evaluating the flowering periods of Mouriri guianensis (Melastomataceae) and the interaction with crepuscular bees highlighted the importance of these bees for the pollination of this plant species, detaching 86 individuals performing crepuscular visits. 

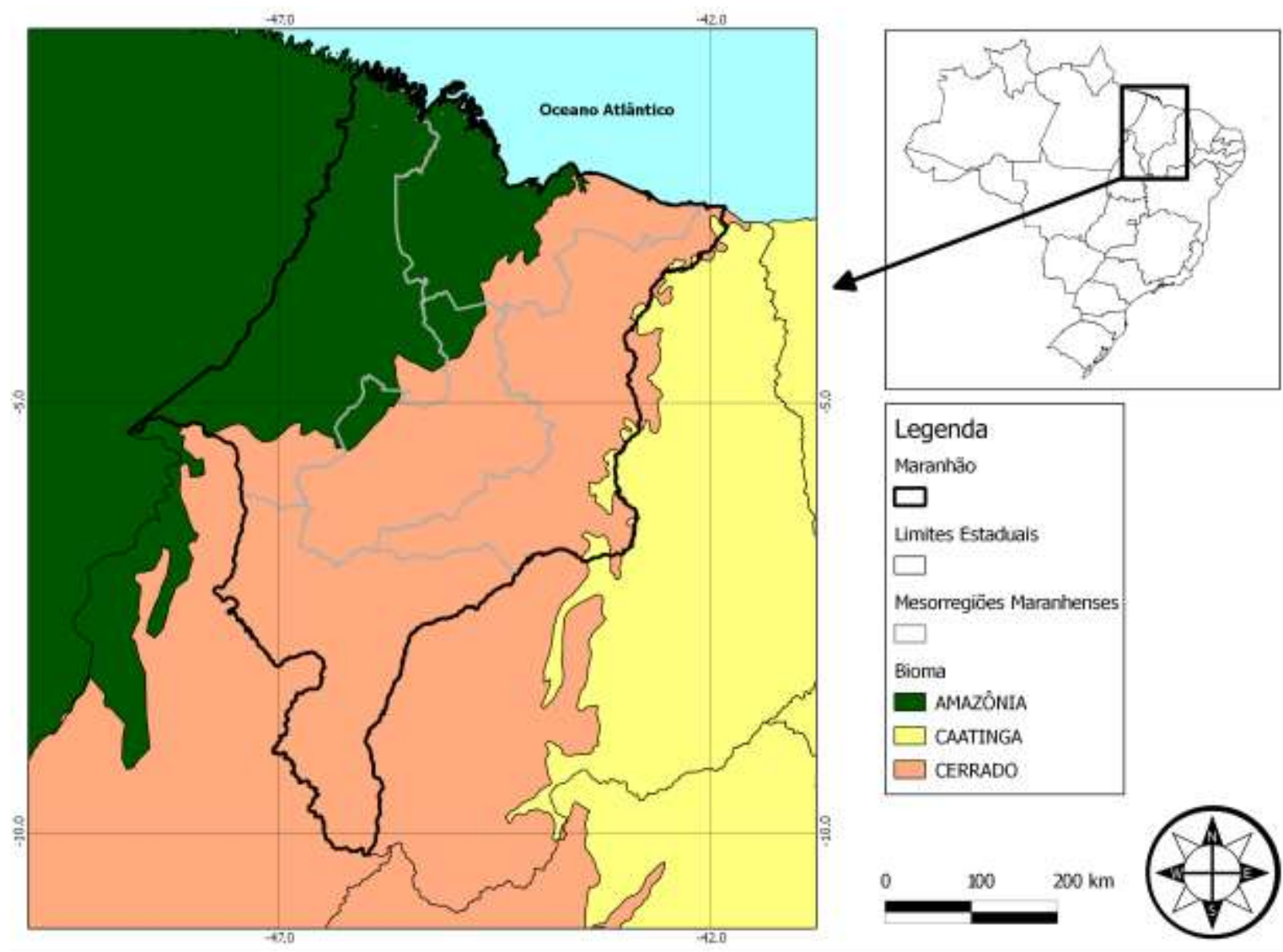

Figure 3. Legal Amazon domain in the state of Maranhão (Brazil).

The maintenance of the structural sandbank mosaic is essential for the preservation of these bees' populations, of their function in the plant community reproduction and in the ecosystem processes (Silva et al., 2009).

Azevedo et al. (2010) inventorying the Phlebotomine communities in São Luís Island and the city of São José de Ribamar, sampled 24 species in five of dense fragments of forest. The authors highlight the importance of surveys for species conservation programs in the region, once the synanthropic of these organisms is harmful to health. For the fauna of Coleoptera, Martins et al. (2009) recorded 123 species of Cerambycidae in six locations of Maranhão, where 114 constituted the first record for the State.

In ectoparasitism studies in rodents in the state of Maranhão Reis et al. (2008) realized that the community of ectoparasites arthropods is composed mainly of Mites of Laelapidae family, and in lesser amounts by other arthropods, such as fleas, lice, and Diptera larvae.

A recently tool used for samplings of species taxonomically undefined is genetic. Fraga et al. (2013) sampled populations of Aedes aegypti of São José de Ribamar, Paço do Lumiar, Raposa and São Luís revealed the existence of two distinct lineages for the state of Maranhão, with the recent introduction. 
Rodrigues et al. (2016) reported that the occurrence of benthic fauna of molluscs to São Marcos Bay, Maranhão State is conditioned on individuals of epifauna, with the main species: Littoraria angulifera and Littoraria flava (1859 individuals), Melampus coffea (3,092 individuals) and Thaisella coronata (805 individuals) and endofauna: Melampus coffea (75 individuals).

For the fish fauna, the inventories are concentrated in four main basins, rivers Pindaré, Tocantins, Parnaíba, and Mearim. However, basins as the rivers Itapecuru and Munim and its tributaries are important ichthyological diversity reservoirs. Piorski et al. (2003), studying the Pindaré and Turiaçu rivers basins, sampled 36 species distributed among 17 families and six orders, highlighting the Characiformes with $41 \%$ of the species. Piorski (2010) inventorying the region of Pindaré and Alto Turiaçu sampled the Characiformes as the most representative, consisting of species with different habits.

Barros et al. (2011) in a survey in Itapecuru river basin were identified 69 species, 29 families, and 10 orders. Characiformes and Siluriformes were the richest orders with 24 and 25 species respectively. The authors also have identified species that are possibly endemic to the region, as Leporinus piau, Schizodon dissimilis, Prochilodus lacustris and species that have been introduced in this basin.

\section{FINAL CONSIDERATIONS}

The northern region stands out for sheltering an economic center widely developed, with a high demography. Constitutes an environment rich in biodiversity terms, such animal as a vegetable, however, is seriously threatened by the exaggerated disturbance of the biomes that are present in the region.

\section{REFERENCES}

Ab'Saber, A.N. 1960. Contribuição à geomorfologia do estado do Maranhão. Notícia Geomorfológica, Campinas, v. 3, n. 5, p. 35-45.

Azevedo, P.C.B.; Lopes, G.N.; Fonteles, RS; VASC.ONCELOS, G.C.; Moraes, J.L.P.; Rebelo, J.M.M. 2011. The Effect of Fragmentation on on Phlebotomine Communites (Diptera: Psychodidae) in Areas of Ombrophilous Forest in São Luís, State of Maranhão, Brazil. Neotrop Entomol, v.40, n.2, p. 271-277.

Bandeira, I.C.N. 2013. Geodiversidade do Estado do Maranhão, Teresina: CPRM.

Barbosa, G.V.; Pinto, M.N. 1973. "Geomorfologia da folha SA.23 São Luís e parte da folha SA.24 Fortaleza". In: Projeto RADAM. Rio de Janeiro, v. 3.

Barros, M.C.; Fraga, E.C.; Birindelli, J.L.O. 2011. Fishes from the Itapecuru River basin, State of Maranhão, northeast Brazil. Braz. J. Biol., v. 71, n. 2, p. 375-380.

Castro, A.C.L. 1986. Aspectos bioecológicos do caranguejo-uçá Ucides cordatus (Linnaeus, 1763), no estuário do Rio dos Cachorros e Estreito do Coqueiro, São Luís, MA. Boletim do Laboratório de Hidrobiologia, São Luís, v. 7, n. 7-26.

Costa, J.B.S.; Borges, M.S.; Igreja, H.L.S.; PINHEIRO, R.V.L., 1991. Aspectos da tectônica cenozóica na região do salgado, litoral nordeste do Estado do Pará. In: III Simpósio de Geologia da Amazônia. Resumos Expandidos. Belém. SBG-Núcleo Norte: 156165. 
Feitosa, A.C. 2006. Relevo do estado do Maranhão: uma nova proposta de classificação topomorfológica. In: SIMPÓSIO NACIONAL DE GEOMORFOLOGIA, 6., 2006, Goiânia. Anais... Goiânia: UGB, 2006. 11 p. 1 CD-ROM.

Ferreira, R.V.; Dantas, M.E. 2010. Relevo do estado do Piauí. In: PFALTZGRAFF, P.A. dos S.; TORRES, F.S. de M.; BRANDÃO, R. de L. (Orgs.). Geodiversidade do estado do Piauí. Recife: CPRM, 2010. 260 p. $30 \mathrm{~cm}+1$ DVDROM. Cap. 5. p. 46-64.

FERRI, M.G. 1980. Vegetação Brasileira. São Paulo, Edusp.

Gastão, F.G.C.; Maia, L.P. 2010. O uso de dados da missão SRTM e sedimentológicos nos estudos de geomorfologia e padrões de drenagem na região dos Lençóis Maranhenses. Revista Brasileira de Cartografia, Rio de Janeiro, v. 62, n. 2, p. 155168.

IBGE. 2002. Instituto Brasileiro de Geografia e Estatística. 2002. Censo Demográfico.

IBGE. 2010. Instituto Brasileiro de Geografia e Estatística. 2010. Censo Demográfico.

IBGE. 2011. Geomorfologia: mapa geomorfológico do Estado do Maranhão. Rio de Janeiro: IBGE.

IBGE. 2011. Pedologia: mapa exploratório de solos do estado do Maranhão. Rio de Janeiro: IBGE.

MARANHÃO. 2002. GEPLAN. Atlas do Maranhão. LABGEO/UEMA, São Luís: GEPLAN.

MARANHÃO. 2011. Secretaria de Estado do Turismo. Plano maior (2010-2020). São Luís: SETUR.

Martins, U.R.; Galileo, M.H.M.; Oliveira, F.L. 2009. Cerambycidae (Coleoptera) do estado do Maranhão, Brasil. Papéis Avulsos de Zoologia, v.49, n.38.
Matos, M.C.B.; Silva, S.S.; Teodoro, A.V. 2016. Seasonal population abundance of the assembly of solitary wasps and bees (Hymenoptera) according to land-use in Maranhão state, Brazil. Revista Brasileira de Entomologia, v. 60. P. 171-176.

Muniz, F.H. 2011. Efeito do manejo florestal sobre a composição florística e fitossociologia da floresta na Amazônia maranhense. In: Marlúcia Bonifácio Martins e Tadeu Gomes de Oliveira (Org.). Amazônia Maranhense: Diversidade e Conservação. Belém: MPEG, p.118-140.

Nobre, C.P.; Ferraz Junior, A.S.L.; Got, B.T.; Berbara, R.L.L.; Nogeira, M.D.C. 2010. Fungos micorrízicos arbusculares em sistema de aléias no Estado do Maranhão, Brasil. Acta Amazônica, v. 40, n.4, p. 641-646.

Novaes, R.C. 2007. Análise da sensibilidade ambiental da parte ocidental da ilha do Maranhão. In: SIMPÓSIO BRASILEIRO DE SENSORIAMENTO REMOTO, 13., 2007, Florianópolis. Anais. Florianopolis: INPE, 2007. p. 4089-4096.

Prost, M.T.R.C. 1997. High intensity short term morpho-sedimentary changes along the French Guyana shoreline documented by remote sensing. In: WORKSHOP DO PROGRAMA INSTITUCIONAL DE ESTUDOS COSTEIROS, 1., 1997, Salinópolis. Anais Salinópolis, 1997. p. 13-15.

Rabelo, A.M.C. 1992. A Dinâmica Costeira na área entre os povoados "Morro do Boi" e "Ponta da Brasília", 1992. Monografia de Conclusão de Curso.

Rego, T.J.A.S.; OLIVEIRA, A.B. 2011. Plantas medicinais de uso corrente na porção amazônica do Maranhão. In: Marlúcia Bonifácio Martins e Tadeu Gomes de Oliveira (Org.). Amazônia Maranhense: Diversidade e Conservação. Belém: MPEG, p.146-165. 
Reis, F.S.; Barros, M.C.; Fraga, E.C.; Penha, T.A.; Teixeira, W.C.; Santos, A.C.G.; Guerra, R.M.S.N.C. 2008. Ectoparasitos de pequenos mamíferos silvestres de áreas adjacentes ao Rio Itapecuru e área de preservação ambiental do Inhamum, Estado do Maranhão, Brasil. Rev. Bras. Parasitol. Vet., v.17, Supl. 1, 69-74.

Rodrigues, C.A.L.; Ribeiro, R.P.; Santos, N.B.; Almeida, Z.S.. 2016. Patterns of mollusc distribution in mangroves from the São Marcos Bay, coast of Maranhão State, Brazil. Acta Amazônica, v. 46, n. 4, p. 391-400.

Senna, C.; Sarmento, A.P. 1996. Aplicações do sensoriamento remoto no mapeamento geobotânico do litoral do NE do Pará. Boletim do Museu Paraense Emílio Goeldi. Botânica, Belém, n. 8, p. 137-155.

Serra, F.C.V.; LIMA, P.B.; ALMEIDA JR., E.B. 2016. Species richness in restinga vegetation on the eastern Maranhão State, Northeastern Brazil. Acta Amazonica, v. 46, n.3, p. 271-280.

Silva, O.; Rego, M.M.C.; Albuquerque, P.M.C.; Ramos, M.C.; 2009. Abelhas Euglossina (Hymenoptera: Apidae) em Área de Restinga do Nordeste do Maranhão. Neotropical Entomology, v. 38, n. 2, p. 186-196.

Silva, Q.D. 2012. Mapeamento geomorfológico da Ilha do Maranhão. Tese (doutorado) - Universidade Estadual Paulista, Faculdade de Ciências e Tecnologia, 249p.

Soares, J.M.A. 2007. Percepção Ambiental Dos Moradores Do Povoado Ponta Do Mangue No Parque Nacional Dos Lençóis Maranhenses, Barreirinhas - Ma. São Luís, 2007. Monografia de Conclusão de curso.

Souza, U.D.V. 2007. Dinâmica da paisagem da área do povoado de Ponta do Mangue, Município de Barreirinhas - Maranhão. Monografia (Graduação) São Luís.

Teixeira, S.G.; Souza Filho, P.W.M. 2009. Mapeamento de ambientes costeiros tropicais (Golfão Maranhense, Brasil) utilizando imagens de sensores remotos orbitais. Revista Brasileira de Geofísica, Rio de Janeiro, v. 27, n. 1, p. 69-82. 